Diklabio: Jurnal Pendidikan dan Pembelajaran Biologi 3(1): 81-90 (Mei 2019) e-ISSN 2598-9669

\title{
PENINGKATAN AKTIVITAS DAN PEMAHAMAN KONSEP MELALUI MODEL KOOPERATIF TIPE PICTURE AND PICTURE
}

\author{
Boy Manto Elperina Manalu' ${ }^{*}$, Sri Irawati ${ }^{1}$, Abdul Rahman ${ }^{1}$ \\ ${ }^{1}$ Program Studi Pendidikan Biologi, Fakultas Keguruan dan Ilmu Pendidikan, Universitas Bengkulu \\ Email: elperinamanalu27@gmail.com
}

\begin{abstract}
Abstrak
Penelitian ini bertujuan untuk meningkatkan aktivitas dan pemahaman konsep peserta didik kelas VIIIC SMPN 7 Kota Bengkulu melalui model kooperatif tipe picture and picture. Jenis penelitian ini termasuk dalam penelitian tindakan kelas dengan metode deskriptif. Penelitian ini terdiri dari dua siklus, setiap siklus terdiri dari empat tahap perencanaan, pelaksanaan, observasi, refleksi. Subyek penelitian adalah guru dan peserta didik kelas VIIIC SMPN 7 Kota Bengkulu pada tahun ajaran 2017/2018 yang berjumlah 30 orang. Instrumen yang digunakan berupa lembar observasi aktivitas guru dan peserta didik, dan lembar tes pemahaman konsep peserta didik. Analisis data dilakukan secara deskriptif dengan menghitung skor rata-rata dan menentukan kriteria aktivitas dan pemahaman konsep peserta didik. Hasil penelitian menunjukkan bahwa rata-rata skor aktivitas guru siklus I 30 (baik), pada siklus II meningkat menjadi 32,5 (baik) dan skor rata-rata aktivitas peserta didik siklus I 29,5 (baik), pada siklus II meningkat menjadi 31 (baik). Persentase nilai klasikal pemahaman konsep peserta didik siklus I 63,33\% (Tidak Tuntas), pada siklus II meningkat menjadi 83,33\% (Tuntas). Kesimpulan dari penelitian ini adalah penerapan model kooperatif tipe picture and picture dapat meningkatkan aktivitas dan pemahaman konsep peserta didik di kelas VIIIC SMPN 7 Kota Bengkulu materi sistem peredaran darah manusia.
\end{abstract}

Kata Kunci: Model Koperatif Tipe Picture and Picture

\begin{abstract}
This research aimed to improve the activity and understanding of the students concept in class VIIIC SMPN 7 Kota Bengkulu by using cooperative model of picture and picture type. This research is classroom action research with descriptive method. This research consists of two cycles, each cycle consists of four stages of planning, implementation, observation, reflection. The subjects of this research was the students of VIIIC class of SMPN 7 Kota Bengkulu in 2017/2018 academic year which was 30 people. The instruments used in this research were the observation sheet of teacher activity and students, and test sheet of understanding of students concept. The analysis of the data was conducted descriptively by calculating the average score and determining the activity criteria and understanding concept of the studen. The results showed that the average score of teacher activity cycle I 30 (good), in the second cycle increased to 32.5 (good) and the average score of activity of students cycle I 29.5 (good), in cycle II increased to 31 (good). The percentage of classical value of the students' understanding of the concept of cycle I 63.33\% (Unfinished), in cycle II increased to $83.33 \%$ (Completed). The conclusion of this research is the application of cooperative model of picture and picture type can increase the activity and understanding the concept of students in class VIIIC SMPN 7 Kota Bengkulu material human circulation system.
\end{abstract}

Keywords: Co-operative Model Picture and Picture Type 


\section{PENDAHULUAN}

Pemerintah Indonesia sedang berupaya mengatasi masalah proses pembelajaran yang lemah dengan cara menerapkan kurikulum 2013. Pola pembelajaran pada kurikulum 2013 dirancang lebih bersifat interaktif dengan berbasis pada jejaring dan kelompok. Selain itu, kurikulum 2013 juga memperbanyak penerapan penggunaan multimedia, menekankan pembelajaran yang aktif untuk mencari dan memperkuat pengembangan potensi khusus setiap peserta didik. Berdasarkan pola pembelajaran ini, peserta didik diharapkan lebih aktif dan kegiatan pembelajaran dapat lebih berpusat pada peserta didik. Kurikulum 2013 telah diaplikasikan pada semua mata pelajaran di tingkat SD hingga SMA termasuk mata pelajaran IPA (Kemendikbud, 2013).

Meskipun telah mengadopsi kurikulum 2013 yang menuntut untuk melibatkan peserta didik lebih aktif dalam pembelajaran, hasil observasi peneliti (saat melaksanakan magang tahun 2017) masih menemukan beberapa masalah pada kegiatan pembelajaran IPA dikelas VIIIC SMPN 7 Kota Bengkulu. Masalah-masalah tersebut antara lain: (1) Aktivitas guru masih sangat dominan dalam kegiatan pembelajaran, (2) Pembelajaran jarang menggunakan multimedia. Pembelajaran menggunakan multimedia dianggap banyak menghabiskan waktu pada persiapan dan penggunaan alat multimedia, dan (3) Peserta didik kurang tertarik dengan pembelajaran IPA Biologi karena dianggap sulit dan banyak hapalan. Permasalahan ini membuat proses pembelajaran menjadi kurang aktif dan hasil belajar yang masih banyak di bawah standar ketentuan minimal sekolah yaitu $\geq 70$. Hasil belajar yang masih rendah disebabkan oleh kurangnya pemahaman konsep peserta didik pada materi yang disampaikan guru. Sehubungan dengan masalah-masalah tersebut, perlu diterapkan suatu model pembelajaran yang diharapkan mampu meningkatkan aktivitas dan hasil belajar peserta didik. Salah satu bentuk yang disarankan untuk diuji coba adalah model kooperatif tipe picture and picture.

Tujuan penelitian ini adalah: (1) Mendeskripsikan penerapan model pembelajaran kooperatif tipe picture and picture materi sistem peredaran darah pada aktivitas mengajar guru dan aktivitas belajar peserta didik kelas VIIIC SMPN 7 Kota Bengkulu. (2) Mendeskripsikan penerapan model pembelajaran kooperatif tipe picture and picture terhadap pemahaman konsep peserta didik kelas VIIIC SMPN 7 Kota Bengkulu materi sistem peredaran darah.

\section{METODOLOGI PENELITIAN}

Jenis penelitian ini adalah penelitian tindakan kelas (PTK). Metode penelitian yang digunakan dalam penelitian ini adalah metode deskriptif. Subyek penelitian ini adalah guru biologi (peneliti) dan seluruh peserta didik kelas VIIIC SMPN 7 Kota Bengkulu yang berjumlah 30 orang yang terdiri dari 14 laki-laki dan 16 perempuan. Variabel yang diteliti terdiri atas variabel bebas yaitu model pembelajaran kooperatif tipe picture and picture dan variabel terikat yaitu aktivitas mengajar guru, aktivitas belajar peserta didik dan pemahaman konsep peserta didik.

Defenisi operasional terdiri atas: (1) Model pembelajaran kooperatif adalah model pembelajaran yang menekankan sikap dan perilaku dalam bekerjasama antar anggota kelompok yang terdiri atas dua orang atau lebih dengan menerapkan tahap pembelajaran kooperatif tipe picture and picture. (2) Aktivitas guru dalam mengajar adalah kegiatan penyampaian materi 
kepada peserta didik dan membimbing peserta didik melakasanakan pembelajaran. Aktivitas peserta didik adalah kegiatan belajar peserta didik dengan menggunakan model pembelajaran kooperatif tipe picture and picture. (3) Pemahaman konsep merupakan kesanggupan peserta didik menangkap makna atau arti dari suatu konsep setelah melaksanakan proses pembelajaran dengan menggunakan model pembelajaran kooperatif tipe picture and picture. Hasil yang diamati berupa ranah kognitif yang diukur dari lembar tes peserta didik mengacu pada Kompetensi Dasar (KD) 3.7 menganalisis sistem peredaran darah pada manusia dan memahami gangguan pada sistem peredaran darah serta upaya menjaga sistem peredaran darah pada manusia.

Teknik pengumpulan data aktivitas guru dan aktivitas peserta didik adalah observasi, dan instrumen yang digunakan yaitu lembar observasi. Teknik yang digunakan untuk mengumpulkan data pemahaman konsep adalah tes uraian dan instrumennya adalah lembar tes. Penelitian ini terdiri dari dua siklus yaitu siklus I dan siklus II. Masing-masing siklus terdiri dari empat tahap yang mengadopsi prosedur penelitian menurut Kunandar (2013) yaitu: (1) Perencanaan, (2) Pelaksanaan, Observasi, (4) Refleksi.

Teknik analisis data observasi aktivitas guru dan peserta didik yaitu dengan rerata skor dan penentuan kategori skor berdasarkan kisaran kategori yang ditetapkan yaitu baik, cukup, kurang, menggunakan rumus:

Rerata skor $(\bar{X})=\frac{\sum X}{N} \quad$ (Winarsunu, 2015)

Ket : $\quad \bar{X}=$ Rata-rata

$\sum X=$ Jumlah skor

$N=$ Jumlah observer
Kategori skor $=\frac{\text { skor tertinggi-skor terendah }}{\text { jumlah } \text { kategori }}$

(Arikunto, 2006)

Teknik analisis data pemahaman konsep peserta didik dianalisis berdasarkan kriteria ketuntasan belajar klasikal menggunakan rumus:

$\operatorname{Rerata}(\bar{X})=\frac{\sum X}{N}$

Keterangan:

$\bar{X}=$ Rata-rata

$\sum X=$ Jumlah skor

$N=$ Jumlah siswa

(Winarsunu, 2015)

Ketuntasan Belajar $(\mathrm{KB})=\frac{\sum X}{N} X 100 \%$

Keterangan:

$\mathrm{KB}=$ Ketuntasan Belajar

$\sum X=$ Jumlah nilai yang tuntas

$\mathrm{N}=$ Jumlah seluruh siswa

(Sudjana, 2006)

\section{HASIL DAN PEMBAHASAN}

Hasil penelitian tindakan kelas pada materi sistem peredaran darah di kelas VIIIC SMPN 7 Kota Bengkulu menunjukkan bahwa model kooperatif tipe picture and picture dapat meningkatkan kualitas pembelajaran. Peningkatan kualitas pembelajaran ini ditandai dengan adanya peningkatan rerata skor aktivitas pembelajaran dan peningkatan persentase nilai klasikal pemahaman konsep peserta didik dari siklus I ke siklus II.

Hasil penelitian ini menunjukkan bahwa selisih rerata dari siklus I dan II pada aktivitas guru mencapai $7.57 \%$, sedangkan pada aktivitas peserta didik mencapai 4,55\%. Hal ini berarti bahwa penerapan model pembelajaran kooperatif tipe picture and picture memiliki dampak positif dengan 
meningkatkan kualitas aktivitas guru dan peserta didik selama pembelajaran.

Berdasarkan hasil observasi kedua observer pada siklus I dan II menunjukkan bahwa pembelajaran IPA biologi materi sistem peredaran darah manusia dengan menerapkan model kooperatif tipe picture and picture sudah terlaksana dengan baik dilihat dari rata-rata skor untuk aktivitas guru sebesar 30 (kategori baik) menjadi 32,5 (kategori baik) dan aktivitas peserta didik dari 29.5 (kategori baik) menjadi 31 (kategori baik). Grafik rerata skor aktivitas guru dan aktivitas peserta didik dapat dilihat pada Gambar 1.

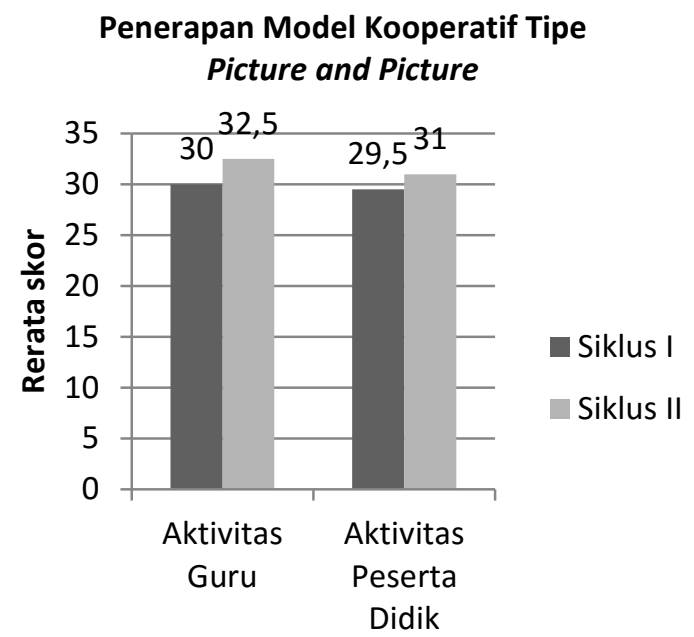

Gambar 1. Grafik rerata skor aktivitas guru dan aktivitas peserta didik

Untuk aktivitas guru dapat dijelaskan melalui beberapa aktivitas diantaranya (Tahap 1), menyampaikan Kompetensi. Pada tahap ini guru membangkitkan minat dan keingintahuan peserta didik terhadap topik pelajaran yang akan dibahas. Pada siklus I guru membangkitkan minat dan keingintahuan peserta didik dengan memberi pertanyaan "Pernahkah bagian tubuh kalian terluka misalnya karena terjatuh atau tergores benda tajam? Apakah bagian tubuh kalian yang terluka mengeluarkan cairan? Apa nama cairan tersebut? dan peserta didik terdorong untuk menjawab pertanyaan dari guru.

Pada tahap ini peserta didik terlihat bersemangat menjawab pertanyaan meskipun suasana kelas masih kurang kondusif. Pada tahap ini guru juga mengajukan pertanyaan dengan menampilkan gambar beberapa jenis makanan "Pada pembelajaran sebelumnya telah dipelajari tentang proses pencernaan. Menurut kalian apa yang mengedarkan zatzat makanan tersebut sampai keseluruh bagian tubuh?". Pada tahap ini belum terlaksana dengan baik, terlihat dari pemberian skor oleh observer I yang menunjukkan kriteria cukup karena guru mengajukan pertanyaan tidak sesuai dengan pengalaman peserta didik tetapi bertanya berdasarkan gambar. Hal ini terjadi karena guru mengalami kesulitan untuk mengkondusifkan peserta didik. Guru terfokus meminta peserta didik untuk memperhatikan pembelajaran yang akan berlangsung. Sehingga guru memilih menjelaskan gambar daripada bertanya kepada peserta didik.

Pada tahap ini guru juga menyampaikan dan menuliskan tujuan pembelajaran. Hal ini bertujuan supaya peserta didik mengetahui tujuan pembelajaran yang akan dipelajari. Pada tahap ini sudah terlaksana dengan baik karena seluruh peserta didik menuliskan tujuan pembelajaran pada buku masingmasing. Selanjutnya pada siklus II guru melakukan perbaikan dengan mengajukan pertanyaan yang membangkitkan minat peserta didik "Pernahkah kalian mengikat ujung jari kalian dengan karet gelang? Apa yang terjadi setelah beberapa saat ujung jari kalian diikat? Mengapa demikian?". Guru juga mengajukan pertanyaan sesuai pengalaman peserta didik "Minggu lalu 
kalian sudah mempelajari organ peredaran darah. Menurut kalian apakah darah yang kalian miliki mengalir keseluruh tubuh atau hanya berada dalam satu organ saja?.

Guru juga membacakan dan menuliskan tujuan pembelajaran di papan tulis supaya peserta didik lebih menahami tujuan pembelajaran yang akan dipelajari. Hal ini sesuai dengan pernyataan Edger Dale dalam Aqib (2013) bahwa peserta didik akan belajar $10 \%$ dari apa yang dibaca, $20 \%$ dari apa yang didengar, 30\% dari apa yang dilihat, serta $40 \%$ dari apa yang didengar dan dibaca.

(Tahap 2) Presentasi materi awal, pada tahap ini guru menyampaikan materi awal sebagai penunjang proses pembelajaran. Pada siklus I yaitu materi komponen penyusun darah dan organ-organ sistem peredaran darah pada manusia. Pada tahap ini belum terlakasana dengan baik karena peserta didik tidak mencatat materi yang disampaikan oleh guru sehingga observer menilai cukup pada tahap ini. Setelah dilakukan refleksi dan pada siklus II yaitu materi siklus peredaran darah dan gangguan pada sistem peredaran darah manusia, guru menyampaikan materi awal dengan baik dan peserta didik sudah mencatat materi yang disampaikan oleh guru setalah diingatkan untuk mencatat materi, hal tersebut dapat dilihat dari skor yang diberikan oleh observer I dan II menunjukkan kriteria baik.

(Tahap 3) Penyajian gambar, pada tahap ini guru mengorganisasikan peserta didik membentuk kelompok yang heterogen (berdasarkan perbedaan kemampuan dan jenis kelamin) dan membagikan lembar diskusi peserta didik pada tiap kelompok. Pada tahap ini sudah terlaksana dengan baik di siklus I dan II. Hal tersebut dapat dilihat dari skor yang di berikan oleh kedua observer menunjukkan kriteria baik. Adanya perbedaan kemampuan peserta didik dapat saling membantu dan bekerjasama memahami konsep yang dipelajari. Hal tersebut sesuai dengan pendapat Sutinah (2015) yang menyatakan bahwa pembagian kelompok kecil yang heterogen dapat membantu anggota kelompok belajar bekerjasama dan saling membantu memahami konsep materi yang diajarkan.

Pada tahap ini guru juga
memperkenalkan gambar puzzle yang
digunakan dalam pembelajaran dan meminta perwakilan kelompok mengambil potongan puzzle. Pada siklus I dan II pembagian potongan puzzle dapat dilaksanakan dengan tertib. Hal tersebut juga dapat dilihat dari skor yang diberikan kedua observer menunjukkan kriteria baik.

(Tahap 4) menyusun puzzle menjadi susunan yang logis, pada tahap ini guru membimbing peserta didik menyusun puzzle menjadi susunan yang logis.Kemudian setiap kelompok mendiskusikan dan menjawab pertanyaan pada lembar diskusi peserta didik. Tahap ini belum terlaksana dengan baik pada siklus I karena guru tidak konsisten dalam pembagian waktu untuk setiap kelompok sehingga guru hanya membimbing 3-4 kelompok peserta didik untuk menyusun puzzle, dan hanya empat kelompok saja yang dapat menyusun puzzle menjadi susunan yang logis sedangkan dua kelompok lainnya masih kebingungan. Hal ini juga terlihat dari skor yang diberikan observer I dan II menunjukkan kriteria cukup pada tahap ini. Pada siklus II kedua observer menilai baik karena guru dapat membagi waktu dan dapat membimbing seluruh kelompok untuk menyusun puzzle, sehingga seluruh kelompok dapat menyusun gambar dengan baik.

(Tahap 5) mengkomunikasikan hasil diskusi, pada tahap ini guru membimbing 
peserta didik mengkomunikasikan hasil diskusi di depan kelas oleh perwakilan kelompok. Pada tahap ini kedua observer menilai cukup sebab belum terlaksana dengan baik disiklus I karena guru hanya dapat membimbing empat kelompok untuk mengkomunikasikan hasil diskusi. Hal tersebut dilakukan untuk mempersingkat waktu karena waktu diskusi banyak tersita pada tahap proses penyusunan gambar. Pada siklus II observer II menilai cukup karena guru masih membimbing empat kelompok saja untuk mengkomunikasikan hasil diskusi. Seharusnya guru lebih konsisten dalam membagi waktu dan dapat membimbing semua kelompok dalam mengkomunikasikan hasil diskusi.

(Tahap 6) menanamkan konsep materi, pada tahap ini guru menyampaikan materi akhir dengan tujuan untuk memperjelas materi yang diajarkan dan memberi penekanan pada materi yang penting untuk diingat oleh peserta didik. Pada siklus I observer masih menilai cukup aktivitas guru dan peserta didik, karena guru menyampaikan materi akhir tanpa memberi penekanan pada konsep yang penting untuk diingat peserta didik dan peserta didik juga hanya empat kelompok saja yang menulis penjelasan materi akhir. Pada siklus II guru melakukan perbaikan dengan menjelaskan materi akhir dan memberi penekanan pada konsep yang penting yaitu siklus peredaran darah dan gangguan pada sistem peredaran darah manusia sehingga observer memberi skor menunjukkan kriteria baik. Sementara untuk aktivitas peserta didik, observer masih menilai cukup karena masih empat kelompok saja yang menuliskan materi akhir. Hal tersebut disebabkan peserta didik malas menulis.

(Tahap 7) penutup, pada tahap ini guru bersama peserta didik membuat kesimpulan hasil pembelajaran. Tahap ini kedua observer memberi skor menunjukkan kriteria baik aktivitas guru dan peserta didik karena guru dan peserta didik membuat kesimpulan hasil pembelajaran di siklus I dan siklus II.

Adapun hasil penelitian yang berkaitan dengan pemahaman konsep menunjukkan bahwa persentase ketuntasan klasikal meningkat sebesar 20\% antara siklus I dan siklus II (Gambar 2). Hal ini berarti bahwa penerapan model pembelajaran kooperatif tipe picture and picture memiliki dampak positif dalam meningkatkan pemahaman konsep peserta didik selama pembelajaran. Persentase nilai pemahaman konsep siswa pada siklus 1 dan siklus 2 dapat dilihat pada Gambar 2.

\section{Persentase Nilai Pemahaman Konsep}

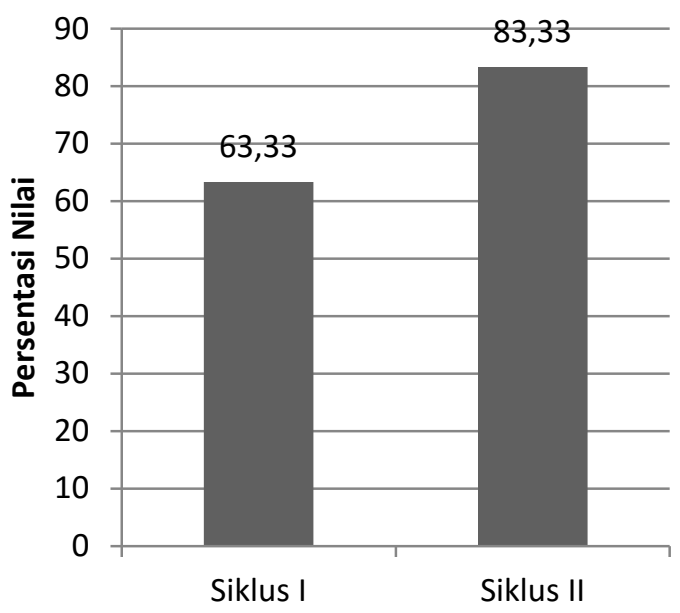

Gambar 2. Grafik persentase nilai pemahaman konsep peserta didik

Hasil tes pemahaman konsep peserta didik pada siklus I menunjukkan bahwa pembelajaran IPA biologi, materi komponen penyusun darah dan organ sistem peredaran darah dengan menerapkan model kooperatif tipe picture and picture belum berlangsung dengan baik. Hal ini dapat dilihat dari perolehan nilai ketuntasan klasikal yang baru mencapai 63,33\% (harapan ketuntasan klasikal 80\%). 
Nilai ketuntasan klasikal ini meningkat hingga $83,33 \%$ pada pelaksanaan siklus II. Peserta didik yang memperoleh nilai $\geq 70$ (batas ketuntasan individu) hanya 25 orang dari 30 peserta didik. Nilai ini mencapai harapan untuk ketuntasan klasikal di SMPN 7 Kota Bengkulu yaitu sebesar $80 \%$. Hal ini menunjukkan bahwa pembelajaran IPA biologi, materi siklus peredaran darah dan penyakit sistem peredaran darah dengan menerapkan model kooperatif tipe picture and picture pada siklus II telah memenuhi target kualitas pembelajaran yang diharapkan.

Peningkatan pemahaman konsep peserta didik dengan menerapkan model kooperatif tipe picture and picture ini dilihat dari meningkatnya hasil tes pemahaman konsep yang diberikan di akhir pembelajaran. Berdasarkan hasil tes pemahaman konsep dengan kategori soal kognitif tingkat $\mathrm{C} 2$ yaitu pemahaman yang terdiri dari 3 indikator kemampuan pemahaman konsep diantaranya yaitu, translasi, interpretasi dan ekstrapolasi. Bentuk soal adalah soal uraian yang bertujuan agar peserta didik menjawab pertanyaan menggunakan kalimatnya sendiri sesuai dengan pemahaman yang mereka peroleh ketika proses pembelajaran berlangsung. Hal ini sesuai dengan pernyataan Arikunto (2016) bahwa soal bentuk uraian menuntut kemampuan peserta didik untuk dapat menginterpretasi, mengorganisir dan menghubungkan pengertian-pengertian yang telah dimiliki dengan menggunakan gaya bahasa dan caranya sendiri.

Pada siklus I materi komponen penyusun darah dan organ sistem peredaran dah manusia, soal yang banyak dijawab benar oleh peserta didik adalah soal no 1 tentang kemampuan translasi (menerjemahkan). Soal nomor 1 berisi materi tentang komponen penyusun darah banyak dijawab benar oleh peserta didik karena peserta didik sudah paham tentang komponen apa saja yang menyusun darah sehingga peserta didik dapat menjelaskan apa yang ditunjukkan oleh gambar dengan menggunakan kalimatnya sendiri. Adapun soal nomor 2 merupakan soal yang lumayan sulit dijawab oleh peserta didik pada siklus I tentang kemampuan interpretasi (menjelaskan) pada sub materi indikator bagian organ-organ jantung. Hal ini dikarenakan peserta didik masih sulit menjelaskan apa yang ada di gambar sehingga kebanyakan jawaban peserta didik mengarah langsung kepada nama-nama bagian yang ditunjuk saja tanpa member penjelasan.

Soal nomor 3 merupakan soal tentang kemampuan interpretasi (membedakan) sebagian dijawab benar oleh peserta didik karena sebagian peserta didik sudah dapat membedakan antara pembuluh darah arteri dan vena serta dapat menjelaskan dengan kalimatnya sendiri tentang gambar tersebut, sebagian peserta didik lagi hanya menyebutkan nama tanpa menjelaskan gambar tersebut. Sedangkan soal nomor 4 merupakan soal tentang kemampuan translasi (menerjemahkan) dijawab benar oleh sebagian peserta didik karena sebagian peserta didik masih kesulitan dalam menerjemahkan gambar ke dalam bentuk kalimat. Sehingga diperoleh rata-rata pemahaman konsep pada siklus I yaitu 66,03 . Hal tersebut menandakan bahwa peserta didik kurang memahami soal-soal terkait indikator pemahaman konsep yang mana pertanyaannya lebih tinggi daripada pertanyaan ingatan (C1). Sebagaimana pernyataan Arikunto (2016) bahwa soal pemahaman menuntut peserta didik untuk menghafal suatu pengertian kemudian menjelaskan dengan kalimat sendiri, 
sehingga dalam menjawab soal pemahaman peserta didik selain harus mengingat juga berpikir.

Kemampuan pemahaman konsep peserta didik mengalami peningkatan setelah dilakukan refleksi pada siklus I. Rerata hasil pemahaman konsep pada siklus II materi siklus peredaran darah dan gangguan sistem peredaran darah meningkat menjadi 75,17 dimana peserta didik sudah dapat menjawab pertanyaan masing-masing indikator pemahaman secara optimal.

Walaupun hasil pemahaman konsep peserta didik meningkat, namun masih banyak peserta didik yang masih kurang paham tentang soal kemampuan translasi (menerjemahkan) pada materi siklus peredaran darah. Selain itu, sebagian peserta didik mengalami kesulitan dalam menjawab soal tentang pemahaman ekstrapolasi (menafsirkan) makna gambar tentang penyakit hipertensi. Hal ini disebabkan peserta didik kurang terbiasa menggunakan gambar dan menurut peserta didik guru jarang memberikan soal-soal yang menggunakan gambar pada penyakit sistem peredaran darah umumnya hanya menggunakan penjelasan saja. Hal tersebut didukung oleh pernyataan Putri (2015) bahwa capaian hasil pemahaman konsep yang kurang optimal dipengaruhi oleh beberapa faktor, diantaranya yaitu peserta didik kurang paham dengan konsep yang telah dipelajari dikarenakan penggunaan metode pembelajaran yang kurang mengaktifkan peserta didik.

Selain itu, pada pembelajaran sebelumnya jarang diberikan soal-soal yang menuntut peserta didik untuk memahami konsep secara optimal, sehingga peserta didik belum terlatih dengan soal-soal pemahaman konsep, terutama soal yang meminta peserta didik untuk menerjemahkan gambar menjadi penjelasan dalam bentuk kalimat.

Peningkatan pemahaman konsep terjadi karena dilakukannya perbaikan penerapan model kooperatif tipe picture and picture di siklus II dengan cara memperbaiki kekurangan yang ada di siklus I yaitu membimbing seluruh kelompok peserta didik dalam mendiskusikan materi, mengkomunikasikan hasil diskusi dan menyimpulkan hasil diskusi serta mempertahankan tahapan yang sudah baik di siklus I. Hal tersebut dikarenakan masingmasing tahap pada model kooperatif tipe picture and picture akan mempengaruhi pemahaman konsep yang akan diperoleh peserta didik, dimana 3 dimensi pemahaman akan berkembang pada setiap tahapan model kooperatif tipe picture and picture.

Kemampuan translasi dan kemampuan interpretasi berkembang saat peserta didik mengamati gambar, terutama pada tahap penyusunan gambar dan pengkomunikasian hasil pemikiran dalam model kooperatif tipe picture and picture. Oleh karena itu, dengan diskusi kelompok peserta didik akan lebih memahami materi dari pada hanya menerima penjelasan dari guru. Hal ini sesuai dengan yang disampaikan oleh Jauhar (2011) dalam Widiadnyana dkk (2014), bahwa mengamati gambar dapat memperbaiki pemahaman dan memperkaya pengetahuan. Adapun Kemampuan menerjemahkan akan berkembang saat peserta didik memperoleh pelatihan untuk menjelaskan gambar. Kondisi ini dapat terbentuk pada model kooperatif tipe picture and picture, mulai dari tahap penyusunan gambar ke bentuk yang logis sampai pada tahap menyimpulkan berdasarkan pengetahuan yang diperoleh. 
Setiap tahapan pada model kooperatif tipe picture and picture yang dilaksanakan dengan baik, maka peserta didik akan memperoleh hasil pemahaman konsep yang optimal karena peserta didik yang membangun sendiri pengetahuan tersebut melalui model kooperatif tipe picture and picture. Berdasarkan hasil penelitian yang telah dilakukan bahwa pembelajaran dengan menerapkan model kooperatif tipe picture and picture melalui pembelajaran IPA biologi di kelas VIIIC SMPN 7 Kota Bengkulu pada materi sistem peredaran darah manusia dalam 2 siklus dapat meningkatkan pemahaman konsep peserta didik dari siklus I ke siklus II. Hal yang sama ditunjukkan dari penelitian Wendi (2016), bahwa penerapan kooperatif tipe picture and picture dapat meningkatkan kemampuan berfikir dan keaktifan peserta didik secara optimal serta dapat meningkatkan hasil belajar peserta didik.

\section{PENUTUP}

\section{Simpulan}

Berdasarkan Penelitian Tindakan Kelas (PTK) yang dilakukan Kelas VIIIC SMPN 7 Kota Bengkulu dengan menerapkan model kooperatif tipe picture and picture pada materi sistem peredaran darah manusia, dapat diperoleh kesimpulan sebagai berikut: (1) Penerapan model kooperatif tipe picture and picture dalam proses pembelajaran IPA Biologi materi sistem peredaran darah di kelas VIIIC SMPN 7 Kota Bengkulu dapat meningkatkan kualitas aktivitas guru dan peserta didik. (2) Penerapan model kooperatif tipe picture and picture dalam proses pembelajaran IPA Biologi pada materi sistem peredaran darah di kelas VIIIC SMPN 7 Kota Bengkulu dapat meningkatkan pemahaman konsep peserta didik.

\section{Saran}

Berdasarkan penelitian yang telah dilakukan, beberapa saran yang dapat dianjurkan yaitu: (1) Diharapkan kepada guru mata pelajaran IPA dalam menerapkan model kooperatif tipe picture and picture dapat memberi puzzle pada setiap kelompok. (2) Untuk peneliti selanjutnya diharapkan peneliti dapat menguasai setiap tahap model kooperatif tipe picture and picture.

\section{DAFTAR PUSTAKA}

Arikunto, Suharsini, 2006. Dasar-dasar Evaluasi Pendidikan. Jakarta: Erlangga

Arikunto,S. 2016. Dasar-dasar Evaluasi Pendidikan. Jakarta: PT Bumi Aksara

Aqib, Zainal, 2013. Model-model, Media dan Strategi Pembelajaran Kontekstual. Bandung: Yrama Widya

Kemendikbud. 2013. Permendikbud Nomor 58 Tahun 2014 Tentang Kurikulum 2013 Sekolah Menengah Pertama / MTs.

Kunandar, 2013. Penelitian Tindakan Kelas Sebagai Pengembangan Profesi Guru. Jakarta: PT Raja Grafindo Parsada

Putri, F,M. 2015. Pengaruh Penerapan Kombinasi Metode Inkuiri dan Reciprocal Teaching terhadap Capaian Pemahaman Konsep Peserta didik. Edusains, 7(1) 2015, 18-26 diakses 19 Juni 2018 di http: //journal. uinjkt. ac. id/index. php/edusains.

Sudjana, 2006. Penilaian Hasil Belajar Proses Belajar Mengajar. Bandung: PT Remaja Rosdakarya

Sutinah. 2015. Model Pembelajaran Kooperatif Tipe Students Team 
Achievement Devision (STAD). Jurnal Penelitian Pendidikan, 1-12.

Wendi, 2016. Penerapan Model Kooperatif Tipe Picture and Picture Untuk Meningkatkan Aktivitas dan Hasil Belajar Peserta didik Kelas XI IPA A SMAN 6 Kota Bengkulu Pada Materi Sistem Pencernaan. Skripsi. Bengkulu. Universitas Bengkulu Winarsunu, Tulus, 2015. Statistik Dalam Penelitian Psikologi Pendidikan. Malang: UMM Press
Widiadnyana, I. W., Sadia, I. W. dan Suastra, I. W. 2014. Pengaruh Model Discovery Learning Terhadap Pemahaman Konsep IPA dan Sikap Ilmiah Peserta didik SMP. E-journal Program Pascasarjana Universitas Pendidikan Ganesha, 4 (1);8-11. Diakses 28 Maret 2018.http://pasca.undiksha.ac.id/e journal/index.php/jurnal ipa/articl e/view/134. 